\title{
Staphylococcus auricularis sp. nov.: an Inhabitant of the Human External Ear $\dagger$
}

\author{
WESLEY E. KLOOS ${ }^{1 *}$ AND KARL H. SCHLEIFER ${ }^{2}$ \\ Department of Genetics, North Carolina State University, Raleigh, North Carolina $27650,{ }^{1}$ and Lehrstuhl für \\ Mikrobiologie, Technische Universität München, D-8000 Munich 2, Federal Republic of Germany ${ }^{2}$
}

A new species, Staphylococcus auricularis, was isolated from the human external ear (external auditory meatus) and is described here. This species can be distinguished from other staphylococci primarily on the basis of growth rate and colony morphology on agar, carbohydrate reaction pattern, cell wall composition, and deoxyribonucleic acid sequence relationships. The type strain of this species is ATCC 33753.

Before the introduction of sound, molecular criteria for distinguishing staphylococci from micrococci, several skin microbiologists reported that micrococci were the most prevalent bacteria of healthy, external human ears (16). Upon reinvestigation of the microflora of human ears, we have found that the predominant grampositive, catalase-positive cocci inhabiting this specific site belong to the new species Staphylococcus auricularis (see below) and to Staphylococcus capitis (7). Of a total of 25 individuals sampled, 23 (92\%) demonstrated populations of $S$. auricularis in the external auditory meatus. In 22 of the 23 individuals, $S$. auricularis was the major Staphylococcus species present in this habitat. Staphylococcus epidermidis, Staphylococcus warneri, Staphylococcus hominis, and Micrococcus kristinae were isolated only occasionally.

In this paper we describe the characteristics of $S$. auricularis, including the criteria establishing it as a new species.

\section{MATERIALS AND METHODS}

Bacterial strains. Staphylococci were isolated by procedures described previously $(8,12)$. A total of 20 strains from 16 different people were selected for this study (Table 1). Each of four of the persons carried two different strains of this species in one ear. The strains of the other species included in this study are listed in Table 2 . All inocula were prepared by aerobic growth of cells on a medium containing peptone, yeast extract, glucose, and $\mathrm{NaCl}$ (P broth or agar) (12). Unless noted otherwise, the incubation temperature was $34^{\circ} \mathrm{C}$.

Character determinations. The procedures used for determining deoxyribonucleic acid (DNA) base composition, colony morphology and pigment, motility, aerobic and anaerobic growth in thioglycolate, salt tolerance, growth temperature, growth on Tween 80 ,

† Paper 33753 of the Journal Series of the North Carolina Agricultural Research Service, Raleigh, N.C. catalase and benzidine activities, acetylmethylcarbinol production, nitrate reduction, coagulase, hemolysis, deoxyribonuclease, alkaline phosphatase, carbohydrate reactions, and susceptibility to various antibiotics, lysozyme, and lysostaphin were similar to the procedures described previously by Kloos and coworkers $(10-13,20)$ for cutaneous micrococci and staphylococci. The preparation of cell walls and the determination of the peptidoglycan type were performed as described by Schleifer and Kandler (18). Cell wall teichoic acids were determined by the procedures of Schleifer and co-workers $(17,21)$. The oxidase test was performed as described by Faller and Schleifer (3). The class of fructose-1,6-biphosphate aldolase was determined by the method of Götz et al. (4). The configuration of the lactic acid produced from glucose was determined by the method of Schleifer and Kocur (21). DNA was isolated and purified by the procedures of Brenner and co-workers (1), as modified by Kloos and Wolfshohl (13). DNA-DNA reassociation reactions and the separation of single-stranded, unreacted DNA from double-stranded, hybridized DNA on hydroxyapatite were performed by the procedures described by Brenner and co-workers (1).

\section{RESULTS AND DISCUSSION}

Description of Staphylococcus auricularis sp. nov. Staphylococcus auricularis (au. ri. cu. la' ris. NL. adj. auricularis pertaining to the ear). The following description of $S$. auricularis is based on a total of 20 strains.

Cells were gram-positive cocci, 0.8 to $1.2 \mu \mathrm{m}$ in diameter, nonmotile, and nonsporeforming and occurred predominantly in tetrads and pairs. Colonies on $\mathrm{P}$ agar were convex, opaque, circular, slightly glistening, white, and very small, ranging from 1.4 to $2.8 \mathrm{~mm}$ in diameter (after incubation for 3 days at $34^{\circ} \mathrm{C}$ and for 2 days at $25^{\circ} \mathrm{C}$ ). Small colony size was also observed on several commercially prepared agar media (e.g., nutrient, tryptic soy, and brain heart infusion agars). The colony texture of $90 \%$ of the strains was smooth; $10 \%$ of strains had colonies with a granular texture and ornate, wrinkled, or rough 


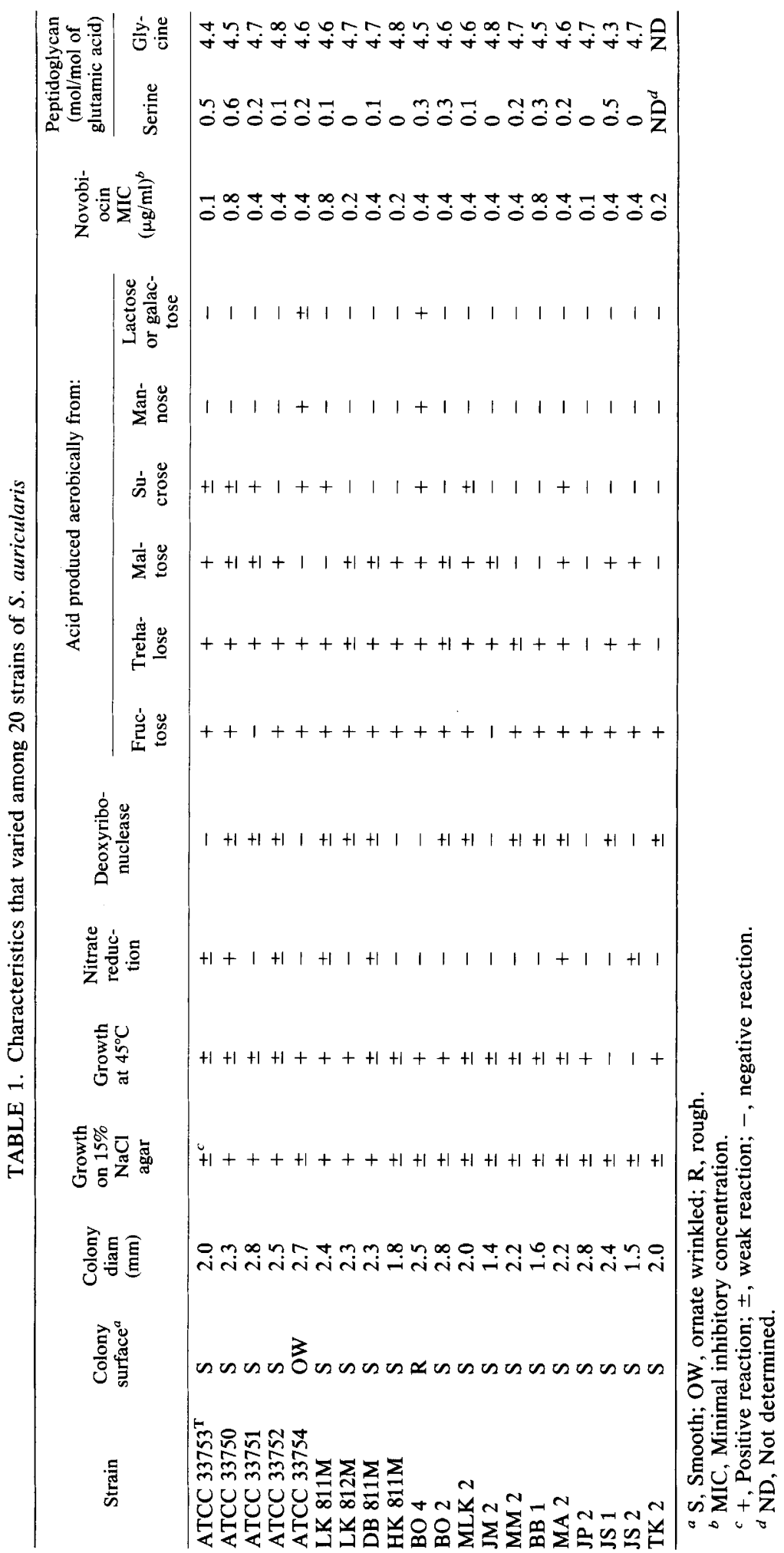


TABLE 2. DNA hybridization of staphylococci with [methyl- $\left.{ }^{3} \mathrm{H}\right]$ thymidine-labeled DNA from $S$. auricularis ATCC $33753^{\mathrm{T}}$

\begin{tabular}{|c|c|c|c|c|c|c|c|}
\hline \multicolumn{2}{|c|}{ Source of unlabeled DNA } & \multicolumn{2}{|c|}{$\begin{array}{l}\% \text { Relative binding }{ }^{a} \text { to } \\
\text { labeled } S \text {. auricularis } \\
\text { ATCC } 33753^{\mathrm{T}} \text { DNA at: }\end{array}$} & \multicolumn{2}{|c|}{ Source of unlabeled DNA } & \multicolumn{2}{|c|}{$\begin{array}{l}\% \text { Relative binding }{ }^{\alpha} \text { to } \\
\text { labeled } S \text {. auricularis } \\
\text { ATCC } 33753^{\mathrm{T}} \text { DNA at: }\end{array}$} \\
\hline Taxon & Strain & $\begin{array}{c}55^{\circ} \mathrm{C} \\
\text { (optimal } \\
\text { conditions) }\end{array}$ & $\begin{array}{c}70^{\circ} \mathrm{C} \\
\text { (stringent } \\
\text { conditions) }\end{array}$ & Taxon & Strain & $\begin{array}{c}55^{\circ} \mathrm{C} \\
\text { (optimal } \\
\text { conditions) }\end{array}$ & $\begin{array}{c}70^{\circ} \mathrm{C} \\
\text { (stringent } \\
\text { conditions) }\end{array}$ \\
\hline S. auricularis & $\begin{array}{l}\text { ATCC } 33753^{\mathrm{T}} \\
\text { ATCC } 33750 \\
\text { ATCC } 33751 \\
\text { ATCC } 33752 \\
\text { ATCC } 33754 \\
\text { LK } 811 \mathrm{M} \\
\text { LK } 812 \mathrm{M} \\
\text { DB 811M } \\
\text { HK } 811 \mathrm{M} \\
\text { BO } 4\end{array}$ & $\begin{array}{r}100 \\
97 \\
93 \\
100 \\
96 \\
99 \\
98 \\
97 \\
98 \\
91\end{array}$ & $\begin{array}{r}100 \\
97 \\
96 \\
99 \\
91 \\
99 \\
97 \\
97 \\
98 \\
90\end{array}$ & $\begin{array}{l}\text { S. saprophy- } \\
\text { ticus } \\
\text { S. cohnii } \\
\text { subsp. } 1 \\
\text { S. cohnii } \\
\text { subsp. } 2 \\
\text { S. cohnii } \\
\text { subsp. } 3 \\
\text { S. xylosus } \\
\text { Staphylococ- }\end{array}$ & $\begin{array}{l}\text { CCM } 883^{\mathrm{T}} \\
\text { ATCC } 29974^{\mathrm{T}} \\
\text { PAY } 12 \mathrm{J3} \\
\text { AU } 5033 \\
\text { ATCC } 29971^{\mathrm{T}} \\
\text { DM } 130\end{array}$ & $\begin{array}{l}34 \\
42 \\
39 \\
\\
35 \\
\\
32 \\
39\end{array}$ & $\begin{array}{r}9 \\
10 \\
7 \\
6 \\
7 \\
10\end{array}$ \\
\hline $\begin{array}{l}\text { S. epidermi- } \\
\quad \text { dis }\end{array}$ & ATCC $14990^{\top}$ & 33 & 7 & $\begin{array}{l}\text { cus sp. } \\
\text { ("3") }\end{array}$ & & & \\
\hline S. capitis & ATCC $27840^{\mathrm{T}}$ & 34 & 10 & S. simulans & ATCC $27848^{\mathrm{T}}$ & 36 & 9 \\
\hline S. hominis & ATCC $27844^{T}$ & 35 & 5 & S. carnosus & $\mathrm{CH}$ & 31 & 7 \\
\hline $\begin{array}{r}S . \text { warneri } \\
\text { subsp. } 1\end{array}$ & ATCC $27836^{\mathrm{T}}$ & 35 & 8 & $\begin{array}{l}\text { S. interme- } \\
\text { dius }\end{array}$ & CFDD & 26 & 8 \\
\hline $\begin{array}{l}\text { S. warneri } \\
\text { subsp. } 2\end{array}$ & PA 13 C11 & 38 & 12 & $\begin{array}{l}\text { S. hyicus } \\
\text { subsp. hyi- }\end{array}$ & NCTC $10350^{\mathrm{T}}$ & 25 & 8 \\
\hline $\begin{array}{l}\text { S. haemolyti- } \\
\text { cus subsp. } \\
1\end{array}$ & ATCC $29970^{\mathrm{T}}$ & 33 & 8 & $\begin{array}{l}\text { cus } \\
\text { S. sciuri } \\
\text { subsp. }\end{array}$ & ATCC $29062^{\mathrm{T}}$ & 24 & 7 \\
\hline $\begin{array}{l}\text { S. haemolyti- } \\
\text { cus subsp. } \\
2\end{array}$ & LED 324 & 35 & 9 & $\begin{array}{l}\text { sciuri } \\
\text { S. sciuri } \\
\text { subsp. len- }\end{array}$ & ATCC $29070^{\mathrm{T}}$ & 28 & 8 \\
\hline S. "simians"' & GOB $18 \mathrm{~F} 3$ & 41 & 13 & tus & & & \\
\hline $\begin{array}{l}\text { S. saccharo- } \\
\text { lyticus }\end{array}$ & ATCC $14953^{\mathrm{T}}$ & 35 & 15 & $\begin{array}{l}\text { S. caseolyti- } \\
\text { cus }\end{array}$ & ATCC 29750 & 13 & 8 \\
\hline S. aureus & ATCC $12600^{\mathrm{T}}$ & 34 & 10 & B. subtilis & ATCC $6051^{\mathrm{T}}$ & 10 & 0 \\
\hline
\end{tabular}

${ }^{a}$ Relative binding data represent the means of duplicate reassociation reactions. The sample standard deviation had a mean of $2 \%$. In the homologous reaction, labeled DNA reassociated with unlabeled DNA at a level of $97 \pm 3 \%$. The percentage of radioactivity bound in the heterologous reaction was normalized to the percentage of radioactivity bound in the homologous reaction. Selected reciprocal reassociation reactions, in which the labeled DNA was from other species (e.g., S. epidermidis ATCC 14990 ${ }^{\mathrm{T}}$, S. hominis ATCC $27836^{\mathrm{T}}, S$. capitis ATCC $27840^{\mathrm{T}}$, S. cohnii ATCC $29974^{\mathrm{T}}$, S. sciuri subsp. lentus ATCC $29070^{\mathrm{T}}$ ) and the unlabeled DNA was from $S$. auricularis ATCC $33753^{\mathrm{T}}$, produced results similar to the data shown above $( \pm 3 \%)$.

${ }^{b} \mathrm{~T}$, Type strain.

surface. The colony edges were entire to slightly undulate and usually became crimpled after 4 to 5 days of incubation. Young colonies ( 1 to 3 days old) exhibited an unusually high profile for staphylococci, which was rather similar to the profiles of certain micrococci (e.g., M. kristinae and Micrococcus sedentarius [12]).

Growth was weak to moderate in the aerobic portion of a semisolid thioglycolate medium and very weak to weak in the anaerobic portion, suggesting a slight facultative anaerobic capability. All strains produced only L-lactic acid from glucose under anaerubic conditions.

All strains grew well at $\mathrm{NaCl}$ concentrations up to $10 \%$. A total of $70 \%$ of the strains grew poorly at an $\mathrm{NaCl}$ concentration of $15 \% ; 30 \%$ of the strains grew moderately at this high salt concentration. The optimal growth temperature range was 30 to $40^{\circ} \mathrm{C}$. No strain grew at $15^{\circ} \mathrm{C}$, and $90 \%$ of the strains grew weakly to moderately at $45^{\circ} \mathrm{C}$.

All strains had a moderate to strong catalase activity, were positive for the benzidine test, and were oxidase negative. Like most staphylococci, all strains contained class I fructose-1,6biophosphate aldolase. All failed to produce coagulases or to exhibit clear hemolysin activity, although upon prolonged incubation (more than 3 days) some partial hemolysis or dark "greening" of the surrounding bovine blood agar medium became evident. A total of $50 \%$ of the strains failed to produce acetylmethylcarbinol, whereas the remaining $50 \%$ produced only low levels of this compound. No strain produced 
alkaline phosphatase activity; $35 \%$ of the strains reduced nitrates to nitrites slowly, and $70 \%$ demonstrated weak deoxyribonuclease activity. Growth was not stimulated by the addition of Tween 80 to $\mathrm{P}$ agar at concentrations ranging from 0.2 to $3 \%$.

All strains produced acid aerobically from D$(+)$-glucose and glycerol; $90 \%$ of the strains produced acid from $\beta$-D-(-)-fructose and $D-(+)$ trehalose, $70 \%$ produced acid from maltose, and $40 \%$ produced acid from sucrose. A total of $10 \%$ of the strains produced acid from D- $(+)$-mannose, $\alpha$-lactose, and $\mathrm{D}$-(+)-galactose, and $5 \%$ produced weak acid from D-(-)-ribose; $35 \%$ of the strains produced very weak acid from $\mathrm{D}-(+)$ turanose. All failed to produce acid from $\beta$ gentiobiose, D-sorbitol, L-(-)-sorbose, salicin, D-(+)-raffinose, L-(+)-rhamnose, xylitol, D- $(+)-$ xylose, $\mathrm{L}-(+)$-arabinose, $\mathrm{D}-(+)$-fucose, mesoinositol, D-mannitol, D-(+)-melezitose, and D(+)-cellobiose.

When we used the API STAPH-IDENT system (Analytab Products, Plainview, N.Y.) with 10 miniaturized biochemical tests (14), all $S$. auricularis strains were negative for alkaline phosphatase, urease, $\beta$-glucosidase, and $\beta$-glucuronidase activities and failed to produce acid aerobically from D-mannitol and salicin. A total of $80 \%$ of the strains produced acid from $\mathrm{D}-(+)-$ trehalose, and $10 \%$ produced acid from D- $(+)-$ mannose; $60 \%$ utilized arginine, and $25 \%$ exhibited weak to moderate $\beta$-galactosidase activity.

All strains were resistant to $50 \mu \mathrm{g}$ of lysozyme per $\mathrm{ml}$ and were susceptible to $100 \mu \mathrm{g}$ of lysostaphin per $\mathrm{ml}$ and $1.6 \mu \mathrm{g}$ of novobiocin per $\mathrm{ml}$. The minimum inhibitory concentration for novobiocin was from 0.1 to $0.8 \mu \mathrm{g} / \mathrm{ml}$. Agar disk diffusion tests indicated that all strains were susceptible to penicillin $G$, methicillin, erythromycin, tetracycline, chloramphenicol, streptomycin, kanamycin, gentamicin, lincomycin, neomycin, vancomycin, and bacitracin $(9,11)$.

All strains contained cell wall peptidoglycan of the basic type Lys-Gly ${ }_{5}$; however, $15 \%$ of the strains had peptidoglycans that had significant amounts of glycine $(0.5$ to $0.6 \mathrm{~mol} / \mathrm{mol}$ of glutamic acid) replaced by serine. All strains possessed an atypical cell wall teichoic acid, namely, $\operatorname{poly}(N$-acetylglucosamine 1 -phosphate) $(15,19)$. The guanine-plus-cytosine contents of the DNAs of the two strains tested (ATCC $33753^{\mathrm{T}}$ [type strain] and ATCC 33754) were 38 and 39 mol\%, respectively. The variable characteristics of the strains are listed in Table 1.

DNA-DNA reassociation reactions performed under optimal and stringent conditions indicated that the 10 strains of $S$. auricularis examined were very closely related $(\geqslant 90 \%$ relative DNA binding or homology) to one another at the species level (Table 2). When S. auricularis and other Staphylococcus species were compared, the DNA homology values were much lower (5 to $15 \%$ under stringent reassociation conditions and, with the one exception of Staphylococcus caseolyticus strain ATCC 29750, 24 to $41 \%$ under optimal reassociation conditions) and were as expected for separate species. These values were significantly higher than those between $S$. auricularis and a member of another gram-positive genus, Bacillus subtilis.

$S$. auricularis can be distinguished from all other staphylococci primarily on the basis of its slow growth and resulting colonial morphology, carbohydrate reaction pattern, cell wall composition, and DNA sequence relationships. There are also some significant differences between this species and some other species in the parameters of cell arrangement, anaerobic growth pattern in thioglycolate, various enzyme activities, and susceptibility to novobiocin $(2,5,6,9$, $11,17,20,21$ ). Simple characters useful in separating $S$. auricularis from other Staphylococcus species are shown in Table 3.

Strain ATCC 33753 (originally designated WK $811 \mathrm{M}$ ) is the type strain of $S$. auricularis. A description of this strain follows.

Cells: spheres 1.0 to $1.2 \mu \mathrm{m}$ in diameter, occurring predominantly in tetrads and pairs. Nonmotile and nonsporeforming. Gram positive.

Agar colonies: circular, entire, convex, smooth with slight glossy surface, opaque, white, and 1.8 to $2.2 \mathrm{~mm}$ in diameter (after 5 days). Older colonies develop a crimpled edge.

Catalase and benzidine tests are positive. Oxidase is negative.

Chemoorganotroph; metabolism is respiratory.

Slightly facultatively anaerobic.

Temperature relationships: no growth at $15^{\circ} \mathrm{C}$ and poor growth at $45^{\circ} \mathrm{C}$; optimum growth temperature, 34 to $37^{\circ} \mathrm{C}$.

Growth on agar containing $\mathrm{NaCl}$ : good growth with $10 \% \mathrm{NaCl}$, poor growth with $15 \%$.

Coagulases are not produced. Nitrates are reduced slowly and weakly; phosphatase and acetylmethylcarbinol are not produced. Deoxyribonuclease activity is very weak. Hemolysins are not detected.

Acid is produced aerobically from glucose, glycerol, fructose, maltose, and trehalose and weakly from sucrose and turanose. No acid is produced from gentiobiose, sorbitol, sorbose, salicin, raffinose, rhamnose, xylose, xylitol, arabinose, fucose, inositol, mannitol, mannose, lactose, melezitose, cellobiose, galactose, or ribose.

Antibiotic susceptibilities: susceptible to lysostaphin $(100 \mu \mathrm{g} / \mathrm{ml})$ and novobiocin $(\geq 0.1$ $\mu \mathrm{g} / \mathrm{ml}$ ); susceptible to penicillin $\mathrm{G}$, methicillin, 


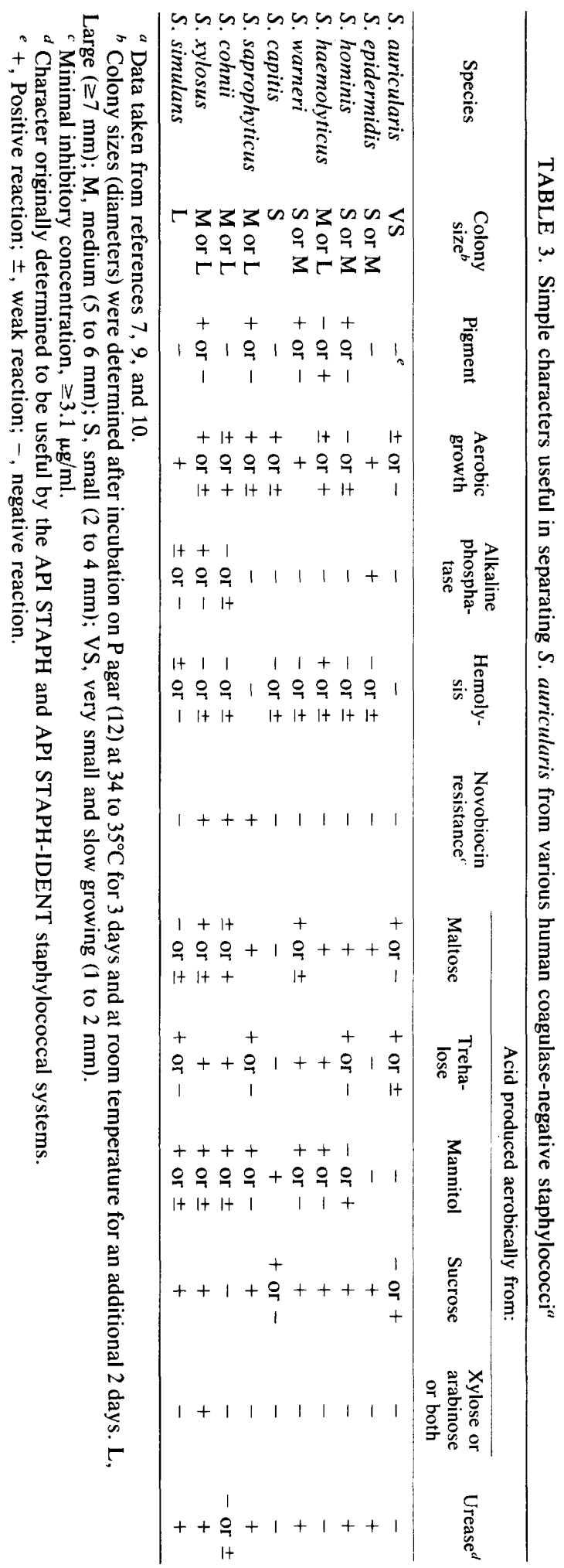


erythromycin, chloramphenicol, streptomycin, kanamycin, tetracycline, gentamicin, neomycin, lincomycin, vancomycin, and bacitracin.

Fructose-1,6-biphosphate aldolase: class I.

Peptidoglycan type: L-Lys-Gly ${ }_{4.4}$, Ser $_{0.5}$.

Cell wall teichoic acid composition: $\operatorname{poly}(N-$ acetylglucosamine 1-phosphate). Atypical.

Guanine-plus-cytosine content of the DNA: $38.8 \mathrm{~mol} \%$.

\section{ACKNOWLEDGMENTS}

We are indebted to V. Marquardt and J. F. Wolfshohl for excellent technical assistance.

This research was supported by a grant from the Deutsche Forschungsgemeinschaft (to K.H.S.) and by North Carolina Agricultural Research Service Project NCO3666 (to W.E.K.).

\section{LITERATURE CITED}

1. Brenner, D. J., G. R. Fanning, A. Rake, and K. E. Johnson. 1969. A batch procedure for thermal elution of DNA from hydroxyapatite. Anal. Biochem. 28:447-459.

2. Devriese, L. A., V. Hajek, P. Oeding, S. A. Meyer, and K. H. Schleifer. 1978. Staphylococcus hyicus (Sompolinsky 1953) comb. nov. and Staphylococcus hyicus subsp. chromogenes subsp. nov. Int. J. Syst. Bacteriol. 28:482490.

3. Faller, A. H., and K. H. Schleifer. 1981. Modified oxidase and benzidine tests for the separation of staphylococci from micrococci. J. Clin. Microbiol. 13:1031-1035.

4. Götz, F., E. Nürnberger, and K. H. Schleifer. 1979. Distribution of class I and class II D-fructose-1,6-biphosphate aldolase in various Gram-positive bacteria. FEMS Microbiol. Lett. 5:253-257.

5. Hajek, V. 1976. Staphylococcus intermedius, a new species isolated from animals. Int. J. Syst. Bacteriol. 26:401408.

6. Kilpper-Bälz, R., and K. H. Schleifer. 1981. Transfer of Peptococcus saccharolyticus Foubert and Douglas to the genus Staphylococcus: Staphylococcus saccharolyticus (Foubert and Douglas) comb. nov. Zentralbl. Bakteriol. Parasitenkd. Infektionskr. Hyg. Abt. 1 Orig. Reihe C 2:331-334.

7. Kloos, W. E. 1982. Coagulase-negative staphylococci. Clin. Microbiol. Newsl. 4:75-79.

8. Kloos, W. E., and M. S. Musselwhite. 1975. Distribution and persistence of Staphylococcus and Micrococcus species and other aerobic bacteria on human skin. Appl. Microbiol. 30:381-395.

9. Kloos, W. E., and K. H. Schleifer. 1975. Isolation and characterization of staphylococci from human skin. II. Descriptions of four new species: Staphylococcus warneri, Staphylococcus capitis, Staphylococcus hominis, and Staphylococcus simulans. Int. J. Syst. Bacteriol. 25:62-79.

10. Kloos, W. E., and K. H. Schleifer. 1975. Simplified scheme for routine identification of human Staphylococcus species. J. Clin. Microbiol. 1:82-88.

11. Kloos, W. E., K. H. Schleifer, and R. F. Smith. 1976. Characterization of Staphylococcus sciuri sp. nov. and its subspecies. Int. J. Syst. Bacteriol. 26:22-37.

12. Kloos, W. E., T. G. Tornabene, and K. H. Schleifer. 1974. Isolation and characterization of micrococci from human skin, including two new species: Micrococcus lylae and Micrococcus kristinae. Int. J. Syst. Bacteriol. 24:79-101.

13. Kloos, W. E., and J. F. Wolfshohl. 1979. Evidence for deoxyribonucleotide sequence divergence between staphylococci living on human and other primate skin. Curr. Microbiol. 3:167-172.

14. Kloos, W. E., and J. F. Wolfshohl. 1982. Identification of Staphylococcus species by use of the API STAPHIDENT system. J. Clin. Microbiol. 16:509-516.

15. MacArthur, H. A. I., F. M. Roberts, I. C. Hancock, and J. Baddiley. 1980. Concomitant synthesis and attachment of cell wall polymers by a membrane preparation from Micrococcus varians ATCC 29750. Bioorg. Chem. 9:5562 .

16. Noble, W. C., and D. A. Somerville. 1974. Microbiology of human skin. W. B. Saunders Co., Ltd., London.

17. Schleifer, K. H., and V. Fischer. 1982. Description of a new species of the genus Staphylococcus: Staphylococcus carnosus. Int. J. Syst. Bacteriol. 32:153-156.

18. Schleifer, K. H., and O. Kandler. 1972. The peptidoglycan types of bacterial cell walls and their taxonomic implications. Bacteriol. Rev. 36:407-477.

19. Schleifer, K. H., R. Kilpper-Balz, V. Fischer, A. Faller, and J. Endl. 1982. Identification of "Micrococcus candidus" ATCC 14852 as a strain of Staphylococcus epidermidis and of "Micrococcus caseolyticus" ATCC 13548 and Micrococcus varians ATCC 29750 as members of a new species, Staphylococcus caseolyticus. Int. J. Syst. Bacteriol. 32:15-20.

20. Schleifer, K. H., and W. E. Kloos. 1975. Isolation and characterization of staphylococci from human skin. I. Amended descriptions of Staphylococcus epidermidis and Staphylococcus saprophyticus and descriptions of three new species: Staphylococcus cohnii, Staphylococcus haemolyticus, and Staphylococcus xylosus. Int. J. Syst. Bacteriol, 25:50-61.

21. Schleifer, K. H., and M. Kocur. 1973. Classification of staphylococci based on the chemical and biochemical properties. Arch. Mikrobiol. 93:65-85. 